BULLETIN OF THE GEOLOGICAL SOCIETY OF AMERICA

VOL. 7, PP. 17-30

NOVEMBER 14, 1895

\title{
DRUMLINS AND MARGINAL MORAINES OF ICE-SHEETS
}

BY WARREN UPHAM

(Presented before the Society August 28, 1895)

CONTENTS

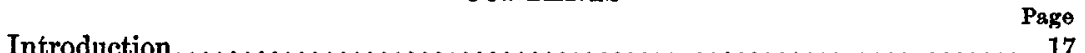

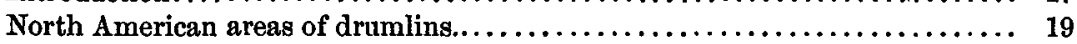

Accumulation of drumlins from englacial drift..................... 21

North American marginal moraines............................ 23

Conditions of formation of marginal moraines.................... 24

Drumlins and moraines both referable chiefly to the Champlain epoch..... 26

European drumlins and moraines.............................. 27

Recognition of the Champlain epoch in Europe.................... 28

Contrast of the growth and decline of the Pleistocene ice-sheets in their depo-

sition of drift............................................. 28

Comparison of present ice action in Alaska and Greenland............ 29

INTRODUCTION.

The chief characteristic of the present stage of investigations of the Ice age and its glacial and modified drift deposits seems to consist in the search, through observations and study, for explanations of the methods in which the ice-sheets of North America, northern Europe, Patagonia, and other glaciated areas, acted in eroding, mingling, transporting and depnsiting the various drift formations.

All the diverse phases of the till or ground moraine, also called boulderclay, from its heterogeneous materials, and including much englacial drift, which was allowed to fall loosely on the ground from the ice during its stages of retreat, are classed together as direct products of the action of land ice, without modification by the assorting, transporting and stratifying agency of streams and lakes formed by the glacial melting and accompanying rains. Most drumlins in their entire mass, and all others in their superficial part, consist of till, an unstratified deposit of intermingled boulders, gravel, sand and clay, in which usually the largest ingredient by measure is the very finely ground rock flour of the glacial grist. Though called clay, the rock flour, on areas of sandstone, 
granites, gneisses or quartzose schists, is made up principally of exceedingly finely comminuted quartz particles.

Likewise the marginal moraines, which record the history and work of the ice-sheets during the fluctuating stages of their wavering final recession, are, along the greater part of their extent, composed mainly of till, with multitudes of boulders. Nearly everywhere also they inclose occasional lenticular or irregular beds of gravel and sand, with here and there superficial knolls and short ridges of similar gravel and sand, called kames. The inner stratified beds and the kames were laid down by streams from the ice melting and from rains, while the till of the moraines was borne and pushed forward by the slowly advancing ice to the limit where the equilibrium of climatic conditions temporarily held the glacial border nearly stationary during any series of years. Less frequently some considerable extent of the marginal drift belt, though amassed in hills 100 to 200 feet high, consists almost wholly of modified drift, being stratified gravel and sand, with only rare inclosed or superficial boulders, forming a prolunged series of gigantic, massively rounded kame deposits, as in the great frontal moraine on Long island, from Roslyn east to Napeague, a distance of about 75 miles.

The purpose of the present paper is to inquire how the ice amassed its prominent, round or oval, and sometimes more elongated, hills of till called drumlins, and how it brought and heaped up the till in its equally conspicuous, but more confusedly grouped, marginal moraine hills, distinguished notably by their irregularity of contour, abundant boulders and extension in series which are traced hundreds and even thousands of miles, from Nantucket, Marthas Vineyard and cape Cod to Wisconsin, Iowa, Minnesota, South and North Dakota, Manitoba and the northwestern plains of Assiniboia, Saskatchewan, and Alberta. Both the drumlins and the moraines are found referable to the Champlain epoch or closing part of the Glacial period, when the country, heavily laden by the icesheet, had sunk from its high preglacial and Glacial elevation, being depressed mostly somewhat below its present height, so that the reign of the Arctic climate, which had deeply covered the land with snow and ice, was rapidly brought to an end by mild temperate conditions nearly like those of the present time in the same latitudes.

For Europe, as well as North America, the drumlins and moraines are shown to be referable to this final Champlain epoch of the Ice age; and the whole history of the Glacial period, in its beginning, successive stages, and end, appears to have been, in a general way, synchronous throughout its series of stages on the two continents. During the growth and culmination of the ice-sheets in both North America and Europe the conditions of glacial action in transportation and deposition of drift were very un- 
like those of the ensuing Champlain epoch, to which the drumlins and marginal moraines chiefly belong. By the depression of the land and consequent return of a temperate climate the ice was rapidly melted away, with steeper frontal gradients, more powerful currents, and more vigorous drift accumulation in the drumlin and moraine hills than during the earlier and longer part of the Ice age, while the land had a high altitude and severely cold climate.

Greenland now in a considerable degree represents the time of growth and maximum extent of the Pleistocene ice-sheets; but Alaska, with its generally receding glaciers, and most notably the Malaspina ice-sheet, having a drift-covered and forest-bearing border, partially illustrates the conditions of the Champlain epoch.

\section{North American Areas of Drumlins.}

Besides the frequent arrangement of the drumlin hills and ridges of till in groups and somewhat definite belts, which are from a few miles to 10 or 20 miles wide, lying approximately parallel with the general course of neighboring marginal moraines, while intervening belts or irregular areas are destitute of drumlins, a still more noteworthy feature of their geographic distribution is found in their occurring thus upon some extensive districts, while they are utterly wanting on larger portions of the great glaciated areas of North America and Europe.

$\mathrm{Mr}$ Robert Chalmers has observed numerous drumlins on the east side of lake Utopia and between the Magaguadavic and Saint Croix rivers in Charlotte, the most southwestern county of New Brunswick.* Under the name "whalebacks," Mr G. F. Matthew describes these and other drumlins in the southern part of this province on an area extending from the Saint Croix about 90 miles east to Upham township. $\dagger$

Drumlins are reported in Maine by Professor George H. Stone, the lenticular type prevailing in the western part of the state, while toward the east they also take the form of long ridges. In size and numbers, however, they are described as inferior to the drumlins of New Hampshire, Massachusetts, and New York.

The earliest mapping of drumlins in this country was done by the writer in 1878, under the direction of Professor C. H. Hitchcock, for the Geological Survey of New Hampshire.\$ Nearly 700 drumlins were noted in the southern half of this state, but throughout its northern half these drift accumulations are absent or very rare. Some 130 drumlins in adja-

\footnotetext{
* Geol. and Nat. Hist. Survey of Canada, Annual Report, new series, vol. iv, for 1888-'89, p. $23 \mathrm{~N}$. † Geol. and Nat. Hist. Survey of Canada, Report of Progress for 1877-78, pp. 12-14 EE.

† Proc. Bos. Soc. Nat. Hist, vol. xx, 1880, p. 434. Proceedings of the Portlend Society of Natural History, March 11 and Nov. 21, 1881.

\& Geology of N. H., atlas and vol. iii, 1878, pp. 285-309, with heliotype.
} 
cent portions of northeastern Massachusetts and southwestern Maine were also noted on this map.

Professors Shaler,Wright, Hitchcock, and Davis, and the present writer, have described the drumlins of Boston and neighboring areas, where they are admirably developed.* During the years 1890 to 1893 the drumlins of the entire state of Massachusetts have been mapped and carefully studied by Mr George H. Barton, under the direction of Professor N. S. Shaler, for the United States Geological Survey. $\dagger$ Their total number is found to be nearly 1,800 , counting, as in New Hampshire, the separate, rounded summits of compound drumlin aggregations, where two or three of these hills, or sometimes more, are merged together at their bases.

Fron, the vicinity of Spencer, Massachusetts, a series of abundant drumlins, according to Davis, extends south to Pomfret, in northeastern Connecticut. They probably also occur plentifully in other parts of this state, reaching southward to Long Island sound, for Round hill, in Orange, near New Haven, described by Professor J. D. Dana, appears to be a drumlin. $\ddagger$

New York has a magnificent area of drumlins, perhaps the most interesting in the United States, which stretches more than 60 miles, from Syracuse westward nearly to Rochester, lying between the south side of lake Ontario and the Finger lakes. $\$$ These hills are well seen along the New York Central and West Shore railroads. Another area of drumlins, occurring in less profusion and less diversity of forms, lies in Jefferson county, between the east end of lake Ontario and the Adirondacks. II

In the drift-covered northern part of New Jersey drumlins are infrequent, only two examples being mentioned by Professor R. D. Salisbury in his preliminary paper on the Pleistocene formations of that state. $\uparrow$

No drumlins have been found in Ohio, Indiana, and Illinois, by $\mathrm{Mr}$ Frank Leverett, Professor G. F. Wright, and others, who have thoroughly

*N. S. Shaler: Proc. Bost. Soc. Nat. Hist., vol. xiii, 1870, pp. 1976-204. Illustrations of the Earth's Surface: Glaciers, 1881, pp. 60-63. U. S. Geol. Survey, Seventh Ann. Rep. for 1886, pp. 321, 322; Ninth Ann. Rep. for 1888 , pp. 550, 551.

G. F. Wright: Proc. Bost. Soc. Nat. Hist., vol. xix, 1876, p. 58, and vol. $x x, 1879$, p. 217. The Ice Age in North America, 1889, chapter xi.

C. H. Hitchcock : Proc. Bost. Soc. Nat. Hist., vol. xix, pp. 63-67.

W. M. Davis : Illustrations of the Eurth's Surface : Glaciers, text deseribing plate xxiv. Proc. Bost. Soc. Nat. Hist., rol. xxi1, 1882, pp. 34, 40-42. Science, vol. iv, pp. 418-420, Oct. 31, 1884. Am. Jour. Sei., III, vol. xxvili, pp. 407-416, Dec., 1884.

Warren Upham : Proc. Bost. Soc. Nat. Hist., vol. xx, 1879, pp. 220-234; vol. xxiv, 1888, pp. 127-141 ; and same vol. xxiv, 1889, pp. 228-248. Am. Jour. Sci., III, vol. xxxv1i, pp. 359-372, May, 1889. Am. Geologist, vol. $x$, pp. 339-362, Dec., 1892.

$\dagger$ Bull. Geol. Soc. Am., vol. 6, 1894, pp. 8-13.

$\ddagger$ Am. Jour. Sei., III, vol. xxvi, 1883, pp. 357-361.

8 L. Johnson: Trans. N. Y. Acad. Sci., vol. i, 1882, pp. 78-80; Annals, do, rol. ii, pp. 249-266. with map. D. F. Lincoln: Am. Jour. Sci., III, vol, xliv, pp. 290-301, Oct., 1892.

|Bull. Geol. Soc. Am., vol. 3, 1892, p. 142.

I Geol. Survey of New Jersey, Ann. Rep. for 1891, p. 74. 
ACCUMULATION OF DRUMLINS FROM ENGLACIAL DRIFT.

examined that area, mapping its marginal moraines and other drift deposits.

Next northwestward, however, drumlins are again encountered in great abundance and variety in the eastern part of Wisconsin. Professor T. C. Chamberlin estimates their number in that district and the adjoining northern peninsula of Michigan to be not less than 5,000*

Throughout a large region extending thence north westward, comprising Minnesota, northern and central Iowa, South and North Dakota, and southern Manitoba, Professor N. H. Winchell's and my own exploration and mapping of the drift and its marginal moraines have failed to discover any of the peculiarly moulded masses of till classed as drumlins.

Beyond this region drumlins have been reported only by Mr J. B. Tyrrell in lake Winnipegosis, where they form groups of lenticular and elongated low islands, $\nmid$ and similarly in Cree lake and the country southeast of lake Athabasca, from 400 to 500 miles still farther northwest. $\ddagger$

\section{Accumulation of Drumlins from englacial Drift.}

Whenever the warm climate terminating the Glacial period extended unchecked through many years, the depth of the ablation or superficial melting of the outer part of the ice-sheet was probably not less than 15 to 25 feet each summer, as has been observed on the Muir glacier, in Alaska, and on the Mer de Glace, in Switzerland. At such rates of melting any district enveloped by ice 2,000 to 4,000 feet thick, as was true of the central portions of New England and doubtless also of a broad belt thence west to the Laurentian lakes and to Minnesota and southern Manitoba, would be uncovered in one or two centuries, and the recession of the Glacial boundary would average probably a half mile or more yearly.

During any long series of years when the ice-sheet was being thus rapidly melted, its outer portion to a distance of probably five or ten miles from its boundary, being reduced by ablation to a thickness ranging from 100 or 200 feet near the edge upward to 1,000 feet or more, would bear on its surface, especially in the valleys and hydrographic basins of its melting, much drift which had been before contained in the higher part of the ice.§ Only scanty englacial drift, mainly consisting of boulders borne away from hills and mountains, appears to have existed at altitudes exceeding 1,000 or 1,500 feet; but all the lower ice probably contained an increasing proportion of detritus and boulders which had been

* Proc. Am. Assoc. Adv. Sei., vol. xxxv, for 1886, p. "004.

† Geol. and Nat. Hist. Survey of Canada, Ann. Rep., new series, vol. iv, for 1888-'89, p. 22A. Bull. Geol. Soc. Am., vol. 1, 1890, p. 402.

† Geol. Survey of Canada, Ann. Rep., new series, vol. vi, for 1892-93, p. 15A (1892). Am. Geologist, vol. $x i$, pp. 132, 175, Feb. and March, 1893.

\& Ball. Geol. Soc. Am., vol. iii, 1892, pp. 134-148; vol. v, 1894, pp. 71-86. Am. Geologist, vol. viii, pp. 376-385, Dec., 1891 ; vol. x, pp. 339-362, Dec., 1892; vol. xii, pp. 36-43, July, 1893. 
brought into it from below by upward movements due to faster flow of the central and upper glacial currents than of those retarded by friction on the ground. The thinned border of the ice-sheet upon the belt having a remaining thickness of less than 1,000 feet would therefore become covered with drift, as Russell has described the borders of the Malaspina glacier or ice-sheet, which stretches from the Mount Saint Elias range to the ocean.

At many times the general recession of the ice-sheet was temporarily interrupted. The return of a prevailingly cold climate for several decades of years, or occasionally, as we may suppose, for a century or more, brought increased snowfall, which sufficed to hold the ice boundary nearly stationary, perhaps frequently first having pushed it again a considerable distance forward. The thick ice lying far back from the border may then have flowed over its previously thin and drift-covered outer belt, aiding with the new snowfall to envelop the once superglacial drift stratum within the ice-sheet. With the increased thickness and steeper gradient of the outer part of the ice-sheet while the recession of its boundary was slackened, wholly stopped, or changed to a re-advance, due mainly to very abundant snowfalls, much drift which had been formerly exposed on the ice surface would become again englacial, so that a stratum of drift several feet thick might be enclosed in the ice at an altitude increasing inward from less than 50 feet to 500 feet or more.

The upper current of the thickened ice above the englacial bed of drift would move faster than that drift, which in like manner would outstrip the lower current of the ice in contact with the ground. Close to the glacial boundary, whether it halted and even re-advanced or merely its retreat was much slackened but did not entirely cease, the upper part of the ice must have descended over the lower part. This differential and shearing movement, as I think, gathered the stratum of englacial drift into the great lenticular masses or sometimes longer ridges of the drumlins, thinly underlain by ice and overridden by the upper ice flowing downward to the boundary and bringing with it the formerly higher part of the drift stratum to be added to these growing drift accumulations. The courses of the glacial currents and their convergences to the places occupied by the drumlins were apparently not determined so much by the topography of the underlying land as by the contour of the ice surface, which under its ablation had become sculptured into valleys, hills, ridges, and peaks, the isolation of the elevations by deep intervening hollows being doubtless most conspicuous near the ice margin.

Variability in the rate and manner of departure of the ice-sheet may well account for the geographic distribution of the drumlins, as certain areas of their abundance, neighboring tracts where they are more scat- 
tered, and the rare occurrence of lone drumlins, yet of large size and typical form. With much englacial drift gathered in layers and patches in the lower part of the ice-sheet, the inequalities of ablation and superglacial drainage, when extended at certain times over a somewhat broad belt of the ice border, may have produced convergent currents of the lower ice sufficient for amassing these hills in all their variety of grouping and occasional solitary occurrence.*

\section{North American marginat Moratnes.}

In the subdivision of the Glacial period by Geikie, Chamberlin and others, the time of principal accumulation of marginal moraines is regarded as an epoch distinct from the previous portions of the Ice age; and Chamberlin has named the earlier divisions of this period, when the North American ice-sheet reached its culmination, the Kansan and Iowan stages, while the later moraine-forming time is called the Wisconsin stage, from the magnificent development of the moraines in eastern $W$ isconsin. $\dagger$ Between these glacial stages, which appear well recognizable and synchronous in North America and Europe, these authors suppose that there were prolonged interglacial epochs when the ice-sheets were in large part or wholly melted away. Instead of this view, the Ice age seems to me to have been essentially a single glacial epoch, with moderate fluctuations of the ice borders during both the growth and the wane of the ice-sheet. The marginal moraines I consider to have been very rapidly formed while the ice was retreating from its Iowan stage, with no important general re-advance dividing the Iowan from the Wisconsin or moraineforming stage.

From my studies of the glacial lake Agassiz, whose duration was probably only about 1,000 years, the whole Champlain epoch of land depression, the departure of the ice-sheet because of the warm climate so restored, the accumulation of the great marginal moraines during pauses of the glacial recession, and most of the reëlevation of the unburdened lands, appear to have required only a few (perhaps four or five) thousand years, ending about 5,000 years ago. This closing part of the Glacial period, when the moraines were being amassed, was apparently far shorter than its earlier stages of oncoming and culmination.

Three or four of the most prominent moraines of the country on each side of lake Agassiz were formed contemporaneously with the highest beach of the glacial lake, but the formation of that beach could not have

\footnotetext{
* More detailed statements of this theory are given in the Am. Geologist, vol. $x$, pp. 339-362, Dec., 1892, and in Proc. Bost. Soc. Nat. Hist, vol. xxvi, pp. 2-17. for Nov., 1892, with ensuing discussion by Professor W. M. Davis and Mr George H. Barton, pp. 17-25. A later note which I published in the Am. Geologist, vol. Xr, pp. 194, 195, March, 1895, I should now wish to change so far as it suggested departure from the earlier papers here cited.

†The Gre:t Ice Age, third edition, 1894. Journal of Geology, vol. iii, pp. 241-277, April-May, 1895.
} 
occupied more than a tenth part of the whole duration of the lake, or by rough estimate a hundred years, more or less. The conspicuous belts of morainic hillocks, hills and ridges, consisting of very bouldery till, frequently with much kame gravel and sand, of which I have mapped twelve in Minnesota and North Dakota, and Leverett a still larger number in Illinois, Indiana and Ohio, were therefore probably each amassed within a few years, or at the longest probably no more than 25 or 50 years, even for the accumulation of the prominent Leaf hills, rising 200 to 350 feet above the surrounding country. How could such rapid drift transportation and deposition take place? If this question can be satisfactorily answered, with reference of the moraines, both in North America and Europe, to the time of retreat from the Iowan glacial boundaries, a chief argument, which has been much relied upon by the defenders of the theory of two or several distinct glacial epochs, will be set aside.

\section{Conditions of Formation of marginal Moratnes.}

Englacial drift had been carried by the ice currents in some important amount into the basal quarter or third of the ice-sheet; and when the superficial melting or ablation reduced the ice border to a less thickness, this drift was gradually uncovered upon the ice surface. The rates of ascent of the frontal slope may be assumed, in accordance with the upper limits of glacial action on mountains, and after careful consideration of the surface gradients of the Alpine glaciers and of the Greenland ice-sheet, as 400 feet in the first mile, 200 feet in the second mile, and 150, 120, 100, $85,75,67,60$ and 55 feet in the third to the tenth miles, respectively, attaining an altitude of 1,312 feet, or about a quarter of a mile. Thence we may suppose the ascent to average 50 feet per mile for the next nine miles, by which the altitude of a third of a mile, the probable upper limit of the englacial drift on any area where the ice-sheet had been about a mile thick, would be reached.

On areas where the ice-sheet built up large marginal moraines, and also wherever its drainage from ablation brought exceptional volumes of modified drift, or stratified gravel, sand and clay, directly supplied by the ice melting, we must believe that the amount of the englacial drift was greater than on other tracts having smaller moraines and little modified drift. Let us assume, therefore, for the definite illustrative case in which we are seeking to account for pro minent moraine accumulations, that the total englacial drift in the lower third or 1,760 feet of the ice-sheet was equal to a thickness of 15 feet. This may have been distributed, as shown in the accompanying table, so that the basal ice stratum, 400 feet thick, terminating within the first mile from the front, should contain 5 feet of englacial drift; the stratum, 200 feet thick, terminating in the second mile, 2 feet of drift; the 150 feet of ice terminating in the third 
mile, $1 \frac{1}{2}$ feet of drift; the fourth mile's ice stratum, 120 feet thick, 1 foot of drift; and the stratum of 100 feet in the fifth mile, seven-tenths of a foot. The amount of englacial drift above the altitude of 970 feet, reached at the end of five miles, would be about 5 feet in a thickness of about 800 feet of ice, the upper limit, as before noted, being assumed to be 1,760 feet above the land surface.

The rate of ablation of the ice in the warm summers of the Champlain epoch, with alternating sunshine and still more efficient rains, probably averaged from two to four inches daily during 200 days of the warm portion of each year. In the remaining five and a half months we may suppose that the snowfall and ablation counterbalanced each other, while the ice advance, though diminished on account of the lower temperature, would produce some thickening of the border. Rarely the border thickening during many years of prevailingly low temperature would accumulate drumlins in the manner before described. Frequently when a series of years had a small mean rate of ablation, the ice front remained nearly stationary, giving the conditions necessary for the formation of a marginal moraine; but when the ablation was more rapid, no belt was oceupied by the front so long as to be marked by morainic hills and ridges. An average ablation of two inches per day during 200 days of each year may be assumed as permitting the front to remain on the same line, or with advances and recessions not exceeding a half mile or one mile from that line. The resulting moraine would be heaped irregularly on a belt one to two miles wide.

Conditions of morainic Drift Accumulation.

\begin{tabular}{|c|c|c|c|c|c|c|c|c|}
\hline \multirow[b]{2}{*}{$\begin{array}{l}\text { Ice stratum terminating in suc- } \\
\text { cessive miles. }\end{array}$} & \multicolumn{3}{|c|}{ Ascent of ice surface. } & \multicolumn{2}{|c|}{ Glacial advance. } & \multicolumn{3}{|c|}{ Morainic drift, in feet. } \\
\hline & 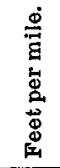 & 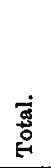 & 迅 & 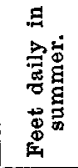 & 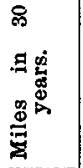 & 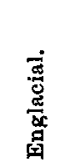 &  & 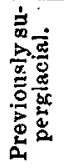 \\
\hline 1 & 400 & 400 & $1: 13$ & 2.1 & 2.5 & 5.0 & 12.3 & 10.0 \\
\hline $2 \ldots \ldots$ & 200 & 600 & $1: 26$ & 4.3 , & 5.3 & 2.0 & 10.6 & 8.0 \\
\hline 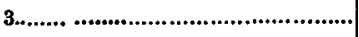 & 150 & 750 & $1: 35$ & 6.8 & 6.7 & 1.5 & 10.0 & 6.6 \\
\hline 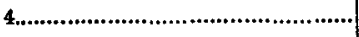 & 120 & 870 & $1: 44$ & 7.3 & 8.7 & 1.0 & 8.7 & 5.5 \\
\hline 5 & 100 & 970 & $1: 53$ & 8.8 & 10.4 & 0.7 & 7.3 & 4.8 \\
\hline \multicolumn{7}{|c|}{$\begin{array}{l}\text { Total average thickness of moraine from these five miles, } 83.7 \text { feet, if amassed } \\
\text { on a belt one mile wide. }\end{array}$} & 48.9 & 34.8 \\
\hline
\end{tabular}

To supply the ice by onflow equivalent to the ablation of two inches daily in summer upon the first mile from the frontal line would require an average forward current of 26 inches daily for the lowest 400 feet of 
the ice-sheet. On the land bed, where it was impeded by friction, the rate.was very small, thence gradually increasing upward. In the second mile the ice would retain its height unchanged under this ablation by an average onflow of 4.3 feet daily for the stratum of ice 200 feet thick terminating in that mile; the third mile would require for its stratum of 150 feet a daily current of 5.8 feet, and the fourth and fifth miles would require currents, respectively, of 7.3 and 8.8 feet. Between nine and ten miles from the ice front, at an altitude of 1,257 to 1,312 feet, the ablation could be offset only by a current of 16 feet daily. By such currents, urged forward by the great weight of the more central and increasingly thicker part of the ice-sheet, the superficial wasting of the ice border would be evenly balanced, holding, therefore, the nearly steady frontal line indispensable for abundant marginal drift deposition. The gradients thus assumed for the ice surface near its boundary are probably twice as steep as they were during the earlier stages of predominant ice accumulation. Hence, with the greatly increased Champlain temperature, the rates of glacial movement were perhaps five or even ten times faster than during the maximum stage of glaciation.

If the outermost five miles of the ice, having the conditions here assumed, remained in essentially unchanged position thirty years, the total volume of drift there becoming superglacial would be equivalent to about 50 feet on a width of one mile. With the previously superglacial drift of the same outer belt of the ice, which, like the foregoing, must have been carried forward to the boundary, there would be a thickness of about 85 feet; and with all received in the same time from the more distant part of the ice surface, up to ten miles from the margin, the total terminal mass of drift would equal at least an average of 100 feet on a belt one mile wide. This amount, amassed by the small frontal oscillations of the ice so as to form irregularly grouped hills and ridges, separated, as those of the moraines usually are, by deep and wide hollows, would constitute a morainic belt probably unsurpassed either in North America or Europe. Under the same conditions, a small but distinct moraine might be formed in only five or ten years; or, where the ice-sheet had less englacial drift, as a quarter or only a tenth as much, the smaller parts of a moraine belt would be made during the same thirty years in which elsewhere its most prominent portions were being deposited.

\section{Drumains and Moratnes both referable chiefly to the Champlain EPOCH.}

From this discussion of the origin of drumlins and marginal moraines it will be seen that their accumulation belonged chiefly to the Champlain epoch of land depression, restored warmth and mainly rapid glacial retreat, interrupted by times when the ice-sheet for several years or decades 
of years held a nearly stationary position. According to the supposition that two inches of daily summer ablation was approximately equaled by the glacial onflow, whenever the ablation was at a faster average rate, as three or four inches daily, the ice receded, depositing the smoother till sheets between the hilly marginal moraine belts.

During the stages of ice accumulation, up to the maximum of the glaciation and to the Iowan stage, I think that the ice-sheet eroded much drift on its central area and bore it forward in the basal quarter or third of the whole thickness of the ice, depositing much of it, however, as subglacial till within fifty miles, more or less, back from its front. When the final recession of the ice carried its border gradually backward over all its area. I believe that the process of subglacial drift deposition continued, forming the ground moraine or lower part of the till progressively as the ice border withdrew, and now and again, under exceptional climatic conditions, amassing much of this till in drum?:ns. The part of the drift which had remained englacial, when the frontal line in its retreat reached the place of a temporary pause, permitting a marginal moraine to be formed, was then borne forward in the manner described to the boundary.

Only with a rate of ablation much faster and with glacial currents much stronger than those of the Arctic regions or of the continental icesheets during their time of accumulation under the severe climate of their high plateau elevation, in short, only during the Champlain epoch, when the land had sunk from its preglacial and Glacial altitude, both in America and Europe, could noteworthy drumlins and peripheral moraines be amassed. They record on each continent the definite closing epoch of the Glacial period.

\section{European Drumlins and Moraines.}

We owe the earliest observations and descriptions of drumlins to Kinahan and Close, in Ireland, and to Shaler, in Massachusetts. These remarkable hills of till are admirably developed in portions of Ireland, Scotland, and northern England. 'To.what extent they exist on the glaciated areas of northern Germany, Russia, and Scandinavia, appears not yet to be clearly ascertained.

During nearly forty years, from the first announcement by Agassiz of his theory that the general drift-sheets of Europe and North America were produced by vast sheets of land ice, their marginal moraines remained unrecognized. Their true character was first made known somewhat less than twenty years ago by Clarence King on the Elizabeth islands of southeastern Massachusetts, Chamberlin in Wisconsin, Lewis and Wright in Pennsylvania, Cook and Smock in New Jersey, and the present writer on Long island, Marthas Vineyard, Nantucket, and cape Cod. After the grand development of these moraines of the North Amer- 
ican ice-sheet had been well explored in their main features from the Atlantic coast to North Dakota, the first discoveries of the similar marginal moraines of the British and European ice-sheets were made less than ten years ago by two American glacialists, who were specially qualified for these observations by their previous work in the United States, namely, Professor H. Carvill Lewis, in Great Britain and Ireland, and Professor R. D. Salisbury, in Germany. It is now ascertained that there are well defined belts of morainic drift hills in southern Sweden, Denmark, northern Germany, and Finland. The most conspicuous German moraine belt is named the Baltic ridge, and the waning ice-sheet at the stage of its formation is known as the great Baltic glacier. All these moraines appear to belong to the same declining part of the Ice age, being correlative with the Wisconsin stage of glaciation in the northern United States.*

\section{Recognition of the Champlain Epoch in Europe.}

The general contemporaneousness of the Glacial period on the opposite sides of the North Atlantic ocean had been long accepted as probable, but its demonstration and the identification of the corresponding parts of the Ice age, having the same sequence on the two continents, were first made known last year by the studies of Geikie and Chamberlin in the new third edition of "The Great Ice Age," and by their later papers this year in the Journal of Geology, as already cited. Not only are the Kansan and Iowan stages of culmination of the ice-sheets closely alike for these widely separated great areas, but also the land depression of the Champlain epoch in both North America and Europe brought marine submergence of coastal tracts and caused rapid disappearance of the icesheets, with the formation of their drumlins and marginal moraines. These two continents were included in the portion of the earth's crust which twice experienced far extended epeirogenic movements, first of high uplift, bringing the cold climate and snow and ice accumulation of the Glacial period, and afterward of depression somewhat lower than now, whereby the vast ice fields were melted away.

\section{Contrast of the Growth and Dechine of the Pleistocene Ice-} SheETs IN their Deposition of Drift.

During the growth and maximum advance of the ice-sheet on each continent the border of the drift along the greater part of its extent was

\footnotetext{
* For a correlation of the stages of the Ice age in North America and Europe leading to the foregoing explanation of the rapid accumulation of the margınal moraines, see the Am. Geologist, vol. zvi, pp. 100-113, Aug., 1895, with maps of the Kansan, Iowan, and Wisconsin boundaries of the North American and European ice-sheets.
} 
GROWTH AND DECLINE OF PLEISTOCENE ICE-SHEETS.

laid down as a gradually attenuated sheet, with neither moraines nor drumlins. After the Kansan or culminating stage the ice retreated and the drift underwent much subaërial erosion and denudation during the Aftonian interglacial stage. Renewed accumulation and growth of the ice in the Iowan stage is again represented by an overlying thin and somewhat even sheet of drift near the limits of that glacial advance, which mostly failed to reach the earlier boundary.

Next came the Champlain epoch of general depression of the ice-burdened lands both east and west of the North Atlantic, when the ice again retreated, but apparently at a much faster rate than before, with great supplies of loess from the waters of its melting. Moderate reëlevation of the tracts earliest uncovered from the ice almost immediately ensued, and a permanent uplift from the Champlain subsidence thence advanced like a wave from the borders toward the center of each of these continental glaciated areas as fast as the ice front retreated. During this glacial recession prominent moraines, in notable contrast with the smooth and comparatively thin outer drift, were amassed in many irregular but roughly parallel belts, where the front at successive times paused or readvanced under secular variations in the prevailingly temperate and even warm climate by which, between the times of formation of the moraines, the ice was rapidly melted away. Occasionally, too, the retreating ice became much thickened near its boundary, giving the peculiar conditions of accumulation of the drumlins, which are somewhat analogous with the marginal moraines. The smooth but steep drumlins are subglacial aggregations of till heaped near the mainly waning ice front, while the rougher moraine hills are its marginal deposits. Both were dependent on secular variations of the average climatic conditions during the Champlain epoch, requiring a few years or decades of years for their formation, according to their varying size, the abundance or scantiness of the englacial drift on and near their areas, and the vigor or feebleness of the glacial currents.

\section{Comparison of present Ice Action in Alaska and Greenland.}

The Malaspina ice-sheet in Alaska has been slowly retreating, like the Muir glacier and others of that country, during the past hundred years or probably much longer. On all its border for a width of a few miles, now thinned perhaps to a quarter part or less of the earlier depth, the waning ice is covered by its formerly englacial drift; but, in that cold climate, the glacial movement is so very slow that forest trees, with luxuriant undergrowth of shrubs, and many herbaceous flowering plants, grow on this drift lying upon hundreds of feet of ice as revealed by stream 
channels. Advancing toward the interior, the explorer soon comes upon higher clear ice and névé, having risen above the plane of the englacial débris, excepting along the course of belts of medial surface morainic drift, swept outward from spurs of the mountains. This ice-sheet partially suggests the conditions of the moraine-forming southern portion of the North American and European ice-sheets during the Champlain epoch; but these had a climate much warmer than that of Alaska, with consequent far more rapid ablation and stronger glacial currents.

In Greenland, on the other hand, the mean temperature has probably been gradually lowered during several centuries past, since the prosperous times of the Norse colonies 900 to 500 years ago. A great ice-sheet, 1,500 miles long with a maximum width of 700 miles, covers all the interior of Greenland; and, although now its extent is less than during the Glacial period, it has doubtless held its own or mainly somewhat increased during several hundred years. While the snow and ice accumulation is predominant, no englacial drift becomes superglacial; but in the region of Inglefield gulf Chamberlin finds the frontal ice-cliffs well charged with englacial débris to a third or half of their total heights of 100 to 200 feet or more. The same ratio of the lower part of the ice-sheet containing drift would quite certainly give it a thickness of 1,000 to 2,000 feet in the deeply ice-covered central portion of Greenland. Other features especially noted are the very distinct stratification of the ice and its differential forward motion, producing not only this stratification, but also sigmoid folds and overthrust faults, where the upper layers move faster than the lower, and these in turn faster than the friction-hindered base. In just the same way, as shown in the foregoing pages, the accelerated currents of the waning ice-sheet during the temperate Champlain epoch overrode each other in succession from the highest to the lowest on the moraine-forming border, bearing a great amount of superglacial drift to the margin, and under certain favorable conditions heaping massive drumlin hills beneath the marginal part of the ice.

If a mild, temperate climate could bring to Greenland the conditions of the Champlain epoch, its thick ice-sheet in the interior under rapid ablation would fully illustrate, as the Malaspina glacier even now does in a considerable degree, the formation of the great series of morainic drift hills and the diversely grouped drumlins which mark stages in the retreat of the continental ice-sheets. 


\section{Geological Society of America Bulletin}

\section{Drumlins and marginal moraines of ice-sheets}

Warren Upham

Geological Society of America Bulletin 1895;7, no. 1;17-30 doi: 10.1130/GSAB-7-17

Email alerting services

Subscribe

Permission request click

www.gsapubs.org/cgi/alerts to receive free e-mail alerts when new articles cite this article

click

www.gsapubs.org/subscriptions/ to subscribe to Geological Society of America Bulletin

click

http://www.geosociety.org/pubs/ copyrt.htm\#gsa to contact GSA

Copyright not claimed on content prepared wholly by U.S. government employees within scope of their employment. Individual scientists are hereby granted permission, without fees or further requests to GSA, to use a single figure, a single table, and/or a brief paragraph of text in subsequent works and to make unlimited copies of items in GSA's journals for noncommercial use in classrooms to further education and science. This file may not be posted to any Web site, but authors may post the abstracts only of their articles on their own or their organization's Web site providing the posting includes a reference to the article's full citation. GSA provides this and other forums for the presentation of diverse opinions and positions by scientists worldwide, regardless of their race, citizenship, gender, religion, or political viewpoint. Opinions presented in this publication do not reflect official positions of the Society.

(C) 1895 Geological Society of America

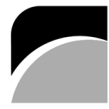

THE GEOLOGICAL SOCIETY OF AMERICA 
Downloaded from gsabulletin.gsapubs.org on August 5, 2015

\section{Notes}

(C) 1895 Geological Society of America

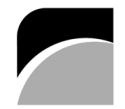

\section{THE GEOLOGICAL SOCIETY OF AMERICA}

